\title{
Genetic studies of Type 2 (non-insulin-dependent) diabetes mellitus: lack of association with seven genetic markers
}

\author{
S. Iyengar ${ }^{1}$, R.F.Hamman ${ }^{2}$, J.A. Marshall ${ }^{2}$, J.Baxter ${ }^{2}$, P.P. Majumder ${ }^{1}$ and R. E.Ferrell $^{1}$ \\ ${ }^{1}$ Human Genetics Division, Graduate School of Public Health, University of Pittsburgh, Pittsburgh, Pennsylvania, and \\ ${ }^{2}$ Department of Preventive Medicine and Biometrics, University of Colorado School of Medicine, Denver, Colorado, USA
}

\begin{abstract}
Summary. Type 2 (non-insulin-dependent) diabetes mellitus, a disease of complex aetiology, has been reported to be nonrandomly associated with several polymorphic markers in human populations. These data, plus evidence of a high prevalence of Type 2 diabetes mellitus in American Indians and mixed populations, such as Mexican-Americans, which is only partially attributable to the prevalence of obesity in these populations, makes it imperative that the nature of such associations be clarified in relation to genetic susceptibility to Type 2 diabetes mellitus. The present paper reports the results of tests of association between Type 2 diabetes mellitus and seven polymorphic markers: the blood groups - ABO, Rhesus, Duffy and Kell (K and KP) - haptoglobin and group specific component; among Anglo and Hispanic populations in the San Luis Valley of Colorado, USA. The sample population consisted of 788 individuals of which 398 were Anglo subjects ( 97 Type 2 diabetes mellitus patients and 301 normal
\end{abstract}

individuals) and 390 Hispanic subjects (191 Type 2 diabetes mellitus patients and 199 normal individuals). Association between Type 2 diabetes mellitus and genetic markers in patients was tested using the $G^{2}$ statistic within each ethnic class using normal frequencies as a comparison. Results of the tests indicated that only the Kell blood group was significantly associated with Type 2 diabetes mellitus at a 5\% level among the Anglo subjects $\left(\mathrm{G}^{2}=5.16,1 \mathrm{df}\right)$. This significant value can be explained by chance alone, if multiple comparisons are taken into account. Our tests have not shown the previously reported haptoglobin or Rhesus blood group associations seen in Mexican-Americans in San Antonio, Texas.

Key words: Type 2 (non-insulin dependent) diabetes mellitus, association, Rhesus blood group, haptoglobin, group specific component.
Discovery of associations between a disorder and polymorphic genetic markers, with a known pattern of inheritance, has often provided insights into the inheritance of disease susceptibility. Investigators have thus attempted to demonstrate non-random associations between diseases and various blood groups. More recently, both protein polymorphisms and restriction fragment length polymorphisms have also been used in the search for disease associations.

Differences in frequencies of phenotypes at marker loci between Type 2 (non-insulin-dependent) diabetic patients and control subjects in various populations have been reported in the literature. Examples include properdin factor B and glyoxylase, non-HLA markers present on chromosome 6. Both these showed a significant decrease in frequency in Polynesian Type 2 diabetic patients [1]. The same trend is also evident in Micronesians and Melanesians although the differen- ces are not statistically significant. Berg et al. [2] and Scholz et al. [3] documented associations in Caucasians between Type 2 diabetes mellitus and the immunoglobulin heavy chain polymorphism on chromosome 14. Kirk et al. [1] noted that the 6-phosphogluconate dehydrogenase allele, 6PGD*A, showed a significant increase in Melanesian diabetic patients. This trend was consistent with the increase in other populations such as Polynesians, Micronesians and Fiji Indians, although the increases in these populations were not significant at the 5\% level. Candien et al. [4] reported that significant differences existed between diabetic patients and control subjects in Pima Indians with respect to the distribution of phosphoglycolate phosphatase phenotypes. This association was not confirmed by Stern et al. [5] in a population based study of Mexican-Americans and non-Hispanic Caucasian adults. 
Table 1. Results of tests of association between Type 2 (non-insulindependent) diabetes mellitus and erythrocyte antigens

\begin{tabular}{|c|c|c|c|c|c|c|c|}
\hline \multirow[b]{2}{*}{$\begin{array}{l}\text { Mar- } \\
\text { ker }\end{array}$} & \multirow[b]{2}{*}{$\begin{array}{l}\text { Pheno- } \\
\text { type }\end{array}$} & \multicolumn{3}{|c|}{ Anglo subjects } & \multicolumn{3}{|c|}{ Hispanic subjects } \\
\hline & & $\begin{array}{l}\text { Type } 2 \\
\text { diabetes }\end{array}$ & $\begin{array}{l}\text { Nor- } \\
\text { mal }\end{array}$ & $\mathrm{G}^{2}$ & $\begin{array}{l}\text { Type } 2 \\
\text { diabetes }\end{array}$ & $\begin{array}{l}\text { Nor- } \\
\text { mal }\end{array}$ & $\mathrm{G}^{2}$ \\
\hline \multirow[t]{6}{*}{$\mathrm{ABO}$} & $\mathrm{A}_{1}$ & 36 & 116 & \multirow[t]{6}{*}{7.14} & 62 & 58 & \multirow[t]{6}{*}{2.77} \\
\hline & $A_{2}$ & 10 & 17 & & 5 & 2 & \\
\hline & B & 6 & 32 & & 12 & 12 & \\
\hline & $\mathrm{A}_{1} \mathrm{~B}$ & 2 & 5 & & 3 & 2 & \\
\hline & $\mathrm{A}_{2} \mathrm{~B}$ & 1 & 0 & & 0 & 0 & \\
\hline & $\mathrm{O}$ & 42 & 131 & & 108 & 125 & \\
\hline \multirow[t]{12}{*}{$\mathrm{RH}^{\mathrm{W}}$} & CDE & 0 & 0 & \multirow[t]{12}{*}{5.60} & 0 & 2 & \multirow[t]{12}{*}{10.20} \\
\hline & CDEe & 2 & 7 & & 7 & 10 & \\
\hline & CDe & 17 & 60 & & 26 & 30 & \\
\hline & $\mathrm{CcDe}$ & 2 & 2 & & 3 & 8 & \\
\hline & CcDEe & 14 & 47 & & 42 & 42 & \\
\hline & $\mathrm{CcDe}$ & 26 & 93 & & 38 & 45 & \\
\hline & $\mathrm{cDE}$ & 4 & 12 & & 18 & 12 & \\
\hline & cDEe & 9 & 33 & & 38 & 27 & \\
\hline & $\mathrm{cDe}$ & 4 & 8 & & 6 & 7 & \\
\hline & Cce & 2 & 2 & & 0 & 0 & \\
\hline & $\mathrm{cEe}$ & 3 & 4 & & 0 & 0 & \\
\hline & $\mathrm{ce}$ & 14 & 33 & & 12 & 16 & \\
\hline \multirow[t]{3}{*}{ Duffy } & $\mathrm{Fy}^{\mathrm{a}}$ & 14 & 44 & \multirow{3}{*}{0.45} & 36 & 46 & \multirow[t]{3}{*}{0.87} \\
\hline & $\mathrm{Fy}^{\mathrm{a}} \mathrm{Fy}^{\mathrm{b}}$ & 35 & 92 & & 63 & 70 & \\
\hline & $\mathrm{Fy}^{\mathrm{b}}$ & 27 & 85 & & 58 & 55 & \\
\hline Kell & $\mathrm{K}(+) \mathrm{k}(-)$ & 0 & 0 & \multirow[t]{3}{*}{$5.16^{\mathrm{x}}$} & 0 & 0 & \multirow[t]{3}{*}{0.16} \\
\hline \multirow[t]{2}{*}{$(\mathrm{K})$} & $\mathrm{K}(+) \mathrm{k}(+)$ & 1 & 18 & & 7 & 6 & \\
\hline & $\mathrm{K}(-) \mathrm{k}(+)$ & 96 & 283 & & 183 & 193 & \\
\hline Kell & $\mathrm{Kp}^{\mathrm{a}}$ & 0 & 0 & \multirow[t]{3}{*}{0.58} & 1 & 0 & \multirow[t]{3}{*}{1.39} \\
\hline \multirow{2}{*}{$(\mathrm{Kp})$} & $K p^{a} K_{p}^{b}$ & 1 & 1 & & 1 & 1 & \\
\hline & $\mathrm{Kp}^{\mathrm{b}}$ & 96 & 300 & & 188 & 198 & \\
\hline
\end{tabular}

$\mathrm{w}$ : Rhesus blood group; $\mathrm{x}$ : significant at the $5 \%$ level with $1 \mathrm{df}$

Stern et al. [5] reported significant associations of Type 2 diabetes mellitus with the Rhesus (RH) blood group and the haptoglobin (HP) phenotypes in Mexican-Americans of San Antonio, Texas, USA. A similar association with the RH blood group had been previously noted be Berg et al. [2] in Norway and by Scholz et al. [3] in Germany. Berg also noticed an association of Type 2 diabetes mellitus with HP. In Mexican-Americans, the HP association is interesting because of an apparent gene dosage effect. Heterozygosity for the HP*1 allele is associated with a $50 \%$ increase and homozygosity for the allele is associated with a $100 \%$ increase in prevalence of Type 2 diabetes mellitus [5]. However, other studies failed to find any significant association of Type 2 diabetes mellitus with $\operatorname{HP}[3,6,7]$.

Finally, several studies have suggested a non-random association between Type 2 diabetes mellitus and the group specific component (GC), which is the serum vitamin $\mathrm{D}$ binding protein. Kirk et al. $[1,8]$ noted a higher frequency of the GC*1 allele in a group of Polynesians with Type 2 diabetes mellitus compared to control subjects. Jorgensen and Hopfer [7] and Cleve [9] have reported similar observations in European populations. Szathmary's studies of subarctic Amerindians showed the GC*1S allele to be associated with higher levels of plasma glucose [10]. Measures of fasting insulin levels in Dogrib Indians indicated that homozygotes for the $\mathrm{GC}^{*} 1 \mathrm{~F}$ allele had the lowest levels of fasting insulin [11].

The present study focuses on association between Type 2 diabetes mellitus and erythrocyte antigens and protein polymorphisms in a population of Anglo and Hispanic subjects in the San Luis Valley of Southern Colorado, USA, particularly the HP, GC and RH loci.

\section{Materials and methods}

\section{Sample}

The San Luis Valley Diabetes Study (SLVDS) is a population based case-control study of risk factors for Type 2 diabetes mellitus and its complications among non-Hispanic Caucasian (Anglo) and Hispanic residents of Alamosa and Conejos counties of the San Luis Valley, Colorado. Each individual who participated in the study was questioned with reference to their Hispanic ethnicity and their diabetic status was determined using a $75 \mathrm{~g}$ oral glucose tolerance test [12]. Details of the criteria used for such definitions as well as methods used to determine other variables are presented in Hamman et al. [13]. The total sample included 950 individuals [13]. Individuals classified as having impaired glucose tolerance [12] $(n=118)$, Type 1 (insulin-dependent) diabetes mellitus patients $(n=26)$, prior 'diabetic individuals' with normal glucose tolerance $(n=15)$ and subjects on whom information was incomplete $(n=3)$ were excluded, leaving a sample of 788 subjects for analysis.

\section{Genetic marker studies}

Blood samples were collected by venipuncture in $8 \mathrm{ml}$ vacutainers containing citric acid-dextrose as an anticoagulant. Samples were shipped from the field to the laboratory on at weekly basis by express mail. Typing of the antigens for the blood groups - ABO, Rhesus, Duffy, and Kell (K and KP) - and HP was carried out as described previously [14]. GC subtyping was done by the method of Kamboh et al. [15].

\section{Statistical analysis}

Data on five blood groups ( $\mathrm{ABO}, \mathrm{RH}, \mathrm{FY}, \mathrm{K}$ and $\mathrm{KP}$ ) and two protein polymorphisms (HP and GC) were used in the tests of association. Information on a few individuals was incomplete at some of the loci due to problems associated with typing blood groups and protein polymorphisms. Thus, in some of the categories there were fewer than 788 individuals present.

In each ethnic group the phenotype frequencies among the diabetic patients were compared to those among the normal subjects. The statistical significance of the association between Type 2 diabetes mellitus and the phenotypes was assessed using the $\mathrm{G}^{2}$ statistic [16], which is defined as:

$$
\mathrm{G}^{2}=2 \mathrm{a}_{\mathrm{ij}} \ln \left[\mathrm{a}_{\mathrm{ij}} / \mathrm{e}_{\mathrm{ij}}\right]
$$

where $a_{i j}$ and $e_{i j}$ denote, respectively, the observed and expected frequencies (under the null hypothesis) of the ij-th cell in the contingency table. Under the null hypothesis of no association, the $\mathrm{G}^{2}$ statistic follows a chi-square distribution with (r-1) (c-1) degrees of freedom (where $\mathrm{r}=$ number of phenotypes and $\mathrm{c}=2=$ number of groups [Type 2 diabetes mellitus and normal]). 
Table 2. Results of tests of associations between Type 2 (non-insulindependent) diabetes mellitus and protein polymorphisms

\begin{tabular}{|c|c|c|c|c|c|c|c|}
\hline \multirow[b]{2}{*}{$\begin{array}{l}\text { Mar- } \\
\text { ker }\end{array}$} & \multirow[b]{2}{*}{$\begin{array}{l}\text { Pheno- } \\
\text { type }\end{array}$} & \multicolumn{3}{|c|}{ Anglo subjects } & \multicolumn{3}{|c|}{ Hispanic subjects } \\
\hline & & $\begin{array}{l}\text { Type } 2 \\
\text { diabetes }\end{array}$ & $\begin{array}{l}\text { Nor- } \\
\text { mal }\end{array}$ & $\mathrm{G}^{2}$ & $\begin{array}{l}\text { Type } 2 \\
\text { diabetes }\end{array}$ & $\begin{array}{l}\text { Nor- } \\
\text { mal }\end{array}$ & $\mathrm{G}^{2}$ \\
\hline \multirow[t]{3}{*}{ Hapto } & $1-1$ & 19 & 46 & 1.25 & 39 & 43 & 0.92 \\
\hline & $1-2$ & 46 & 148 & & 103 & 98 & \\
\hline & $2-2$ & 30 & 106 & & 49 & 58 & \\
\hline \multirow[t]{6}{*}{$G C^{z}$} & $1 \mathrm{~S}-1 \mathrm{~S}$ & 34 & 111 & 5.15 & 53 & 49 & 5.57 \\
\hline & $1 \mathrm{~S}-1 \mathrm{~F}$ & 14 & 50 & & 66 & 67 & \\
\hline & $1 \mathrm{~F}-1 \mathrm{~F}$ & 3 & 9 & & 16 & 12 & \\
\hline & $1 \mathrm{~S}-2$ & 33 & 89 & & 30 & 43 & \\
\hline & $1 F-2$ & 6 & 31 & & 25 & 20 & \\
\hline & $2-2$ & 7 & 9 & & 2 & 6 & \\
\hline
\end{tabular}

$y:$ hapto $=$ haptoglobin

$\mathrm{z}: \mathrm{GC}=$ plasma Vitamin $\mathrm{D}$ binding protein

\section{Results}

The sample sizes and $\mathrm{G}^{2}$ values for testing association between diabetic status and phenotypes are presented in Tables 1 and 2 for erythrocyte antigens and protein polymorphisms. The only statistically significant association that was noted was between Type 2 diabetes mellitus and the Kell blood group $\left(\mathrm{G}^{2}=5.16,2 \mathrm{df}, p<0.05\right)$ among the Anglo subjects. No significant associations with Type 2 diabetes mellitus were observed for the various loci among the Hispanic subjects. Since multiple tests of significance were performed, one significant $\mathrm{G}^{2}$ value is not unexpected because the expected number of significant $G^{2}$ values out of 14 computed is 0.7 at the $5 \%$ level. Thus, this value could be significant by chance alone. Additionally, allelic tests of association were not significant for the alleles at the Kell locus.

\section{Discussion}

Diabetes mellitus is a heterogenous disease of which Type 2 diabetes mellitus and Type 1 diabetes mellitus are the major subgroups [12]. Type 2 diabetes mellitus can be differentiated from Type 1 on the basis of a later age-at-onset, its association with obesity and by the fact that exogenous insulin is often not required to achieve glucose control. Genetically, Type 2 diabetes mellitus has a high concordance rate in monozygotic twins [17], and elevated risk is associated with positive family history. The finding that Type 1 diabetes mellitus is strongly associated with the HLA antigens DR3 and DR4 has contributed significantly to our current understanding of the genetics of Type 1 diabetes mellitus [18, 19]. However, no such marker has yet been identified for Type 2 diabetes mellitus. The discovery of such a marker would facilitate studies of the role of genes in this common disorder.

Our analysis of association between Type 2 diabetes mellitus and several polymorphic markers, previously suggested to be nonrandomly associated with Type 2 diabetes mellitus, using the $\mathrm{G}^{2}$ statistic as a measure of association, did not reveal any evidence of significant association. The lack of consistency in association studies of Type 2 diabetes mellitus in similar populations, Mexican-American subjects of Colorado and Texas, as well as across populations suggests that we have yet to identify a locus that is causally involved in or tightly linked to Type 2 diabetes mellitus susceptibility. Several of the populations where evidence of association between genetic markers and Type 2 diabetes mellitus has been found are hybrid populations formed by recent mixing of parental populations which are genetically distinct $[1,5,8,20]$. This admixture has frequently involved parental populations which differ significantly with respect to the frequency of several genetic markers as well as the background rates of Type 2 diabetes mellitus. This situation complicates the interpretation of any association which may be observed. Thus, consistency of associations across studies may be the only way of distinguishing between real and random association. Despite these problems, the continuing search for association between Type 2 diabetes mellitus and specific genetic markers is worthwhile because of the potential usefulness of a highly associated genetic marker in studies of Type 2 diabetes mellitus susceptibility.

Acknowledgements. This work was supported by NIH grants DK30747 and CRC-RR00051. The authors wish to acknowledge the active support and cooperation of residents of Alamosa and Conejos counties; the San Luis Valley Area Health Education Center; and the core staff of SLVDS: S. Baldwin, R.Cochran, S. Feldman, W. Hildebrandt, O. Martinez, R. Romero, R. Sandoval and J.Apodaca. The laboratory of the University of Colorado Health Sciences Center General Clinical Research Center conducted a majority of the blood chemistry analyses.

\section{References}

1. Kirk RL, Serjeantson SW, King H, Zimmet P (1985) The genetic epidemiology of Diabetes Mellitus. In: Chakraborty R and Szathmary EJE (eds) Diseases of complex etiology in small populations. Alan Liss, New York, pp 119-146

2. Berg K, Aarseth S, Lundevall J, Reinskon T (1967) Blood groups and serum types in diabetes mellitus. Diabetologia $3: 30$

3. Scholz W, Knussmann R, Daweke H (1975) Distribution of blood and serum protein group characteristics in patients with diabetes. Diabetologia 11: 77-82

4. Candien JD, Mamula PW, Hecht F (1979) Phosphoglycolate phosphatase phenotypes and association with Pima Indian diabetes. Am J Hum Genet 31: 40 A (Abstract)

5. Stern MP, Ferrell RE, Rosenthal M, Haffner SM, Hazuda HP (1986) Association between non-insulin dependent diabetes mellitus, Rh blood group and haptoglobin phenotype: results from the San Antonio Heart Study. Diabetes 35: 387-391

6. Simpson NE, Gunson HH, Smithies O (1962) Frequencies of blood groups, serum haptoglobins and levels of slow alpha 2globin in diabetics and their relatives. Diabetes 11:329-333

7. Jorgensen G, Hopfer U (1967) Die Verteilung der Gc-Phanotypen und Gc-allele bei einigen Krankheiten (Diabetes Mellitus, Leberparenchymschaden, Psorasis vulgaris). Humangenetik $3: 227-281$ 
8. Kirk RL, Serjeantson SW, Zimmet $P$ (1982) Genes and diabetes in the Pacific. In: Mimura G, Baba S, Goto Y and Kobberling J, (eds) Clinicogenetic genesis of diabetes mellitus. Excerpta Medica, Amsterdam, pp 34-41

9. Cleve H (1966) Die Verteilung der Gc-Typen und Gc-allele bei Kranken mit diabetes mellitus und chronischer polyarthritis. Humangenetik 2: 355-362

10. Szathmary EJE (1985) The search for genetic factors controlling plasma glucose levels in Dogrib Indians. In: Chakraborty $R$ and Szathmary EJE, (eds) Diseases of complex etiology in small populations. Alan Liss, New York, pp 199-225

11. Szathmary EJE (1987) The effect of Gc genotype on fasting insulin level in Dogrib Indians. Hum Genet 75: 368-372

12. World Health Organization (1985) Diabetes Mellitus, Report of a WHO Study Group, WHO Technical Report Series No.727. Geneva: World Health Organization

13. Hamman RF, Marshall JA, Baxter J, Kahn LR, Mayer EJ, Orleans M, Murphy JR, Lezotte DC (1989) The San Luis Valley Diabetes Study: Methods and prevalence of Non-Insulin Dependent Diabetes Mellitus (NIDDM) in a biethnic Colorado population. Am J Epidemiol 129: 295-311

14. Ferrell RE, Chakraborty R, Gershowitz H, Schull WJ (1981) The St. Lawrence Island Eskimos: Genetic variation and genetic distance. Am J Phys Anthrop 53: 351-358

15. Kamboh MI, Ranford PR, Kirk RL (1984) Population genetics of the vitamin D-binding protein (GC) in the Asian, Pacific area: Description of new alleles at the GC locus. Hum Genet 67:378-384

16. Fienberg SE (1977) The analysis of cross-classified categorical data. Mit Press, Cambridge, MA
17. Rotter JI, Anderson CE, Rimoin DL (1983) Genetics of Diabetes Mellitus. In: Ellenberg $M$ and Rifkin H (eds) Diabetes Mellitus, theory and practice. 3rd edn. Medical Examination, New York, pp 481-504

18. Nerup J, Platz P, Ortved O, Anderson O, Christy M, Lyngsoe J, Poulsen JE, Ryder LP, Staub-Nielsen L, Thomsen M, Svejgaard A (1974) HLA antigens and diabetes mellitus. Lancet II: 864

19. Cudworth AC, Woodrow JC (1975) Evidence for HLA linked genes in juvenile diabetes mellitus. Br Med J 2: 133-135

20. Chakraborty R, Ferrell RE, Stern MP, Haffner SM, Hazuda HP, Rosenthal M (1986) Relationship of prevalence of non-insulin dependent diabetes mellitus to Amerindian admixture in the Mexican Americans of San Antonio, Texas. Genet Epidemiol 3: $435-454$

Received: 27 February 1989

and in revised form: 7 Junie 1989

Dr. R. E. Ferrell

Human Genetics Division

Department of Biostatistics

Graduate School of Public Health

University of Pittsburgh

Pittsburgh, PA 15261

USA 